\title{
Noise from Rail Transport within the European Legislation on Interoperability
}

\author{
K. Neubergová* \\ Department of transport systems, Faculty of Transportation Sciences, Czech Technical University in Prague \\ *Corresponding author: neubergova@fd.cvut.cz
}

DOI: $10.2478 / v 10158-012-0014-3$

\begin{abstract}
This paper is focused on rail transport and the environment, particularly the relationship between noise from rail transport and the directives of the European Union. There are two main areas of legislation on traffic noise originating from the European Commission - Interoperability Directives and Environmental Noise Directive. At the beginning of this paper the noise sources from rail transport are noted. The following sections of this paper present the Directives on interoperability and their historical development. This paper focuses mainly on the role of noise from rail transport in Interoperability Directives. Lastly, the possible measures for reducing noise from rail transport are mentioned.
\end{abstract}

KEY WORDS: Rail transport, noise, interoperability.

\section{INTRODUCTION}

Traffic noise is a serious consequence of transport on the environment. 1996 was a breakthrough year when a core document Green Paper on EU Future Noise Policy was drafted under the European Union. The main goal of this document was to improve the noise situation in the environment. Among the important documents dealing with traffic noise are the directives on interoperability. These directives aim at accelerating the integration of the European Union rail network through increased technical harmonization, thereby guaranteeing a high level of safety. This harmonization also brings with it a significant reduction in noise.

\section{NOISE FROM RAIL TRANSPORT}

Noise is one of the key issues of all transportation, including rail transportation. Rail noise originates mainly from three main sources. The first one is rolling noise, causing by wheelrail interaction. Then there is the power equipment noise, caused by locomotive engine, gears, and fans, and lastly there are aerodynamic effects. Sources of rail noise are represented in Figure 1. Rail exterior sound sources depend on train speed (see Figure 2 (Hemsworth, 2008)). 


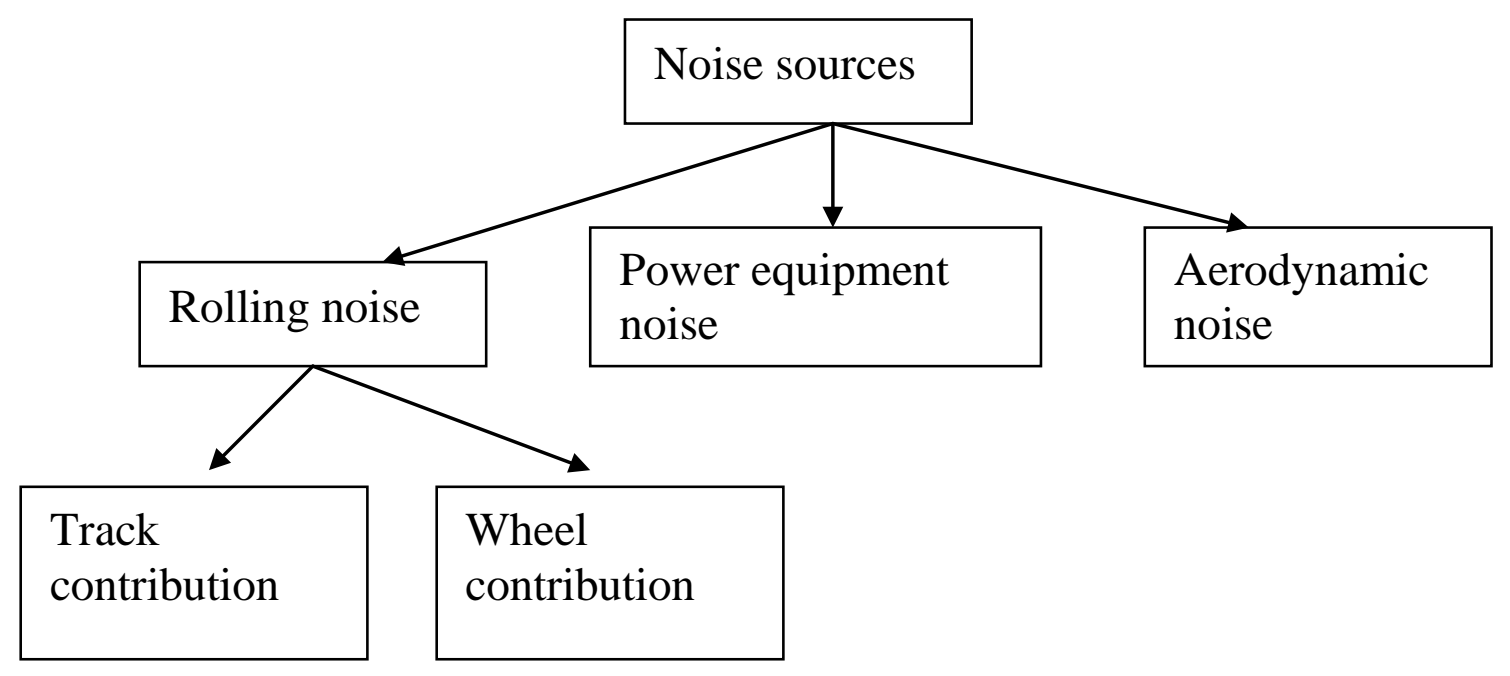

Figure 1: Noise sources from rail transport.

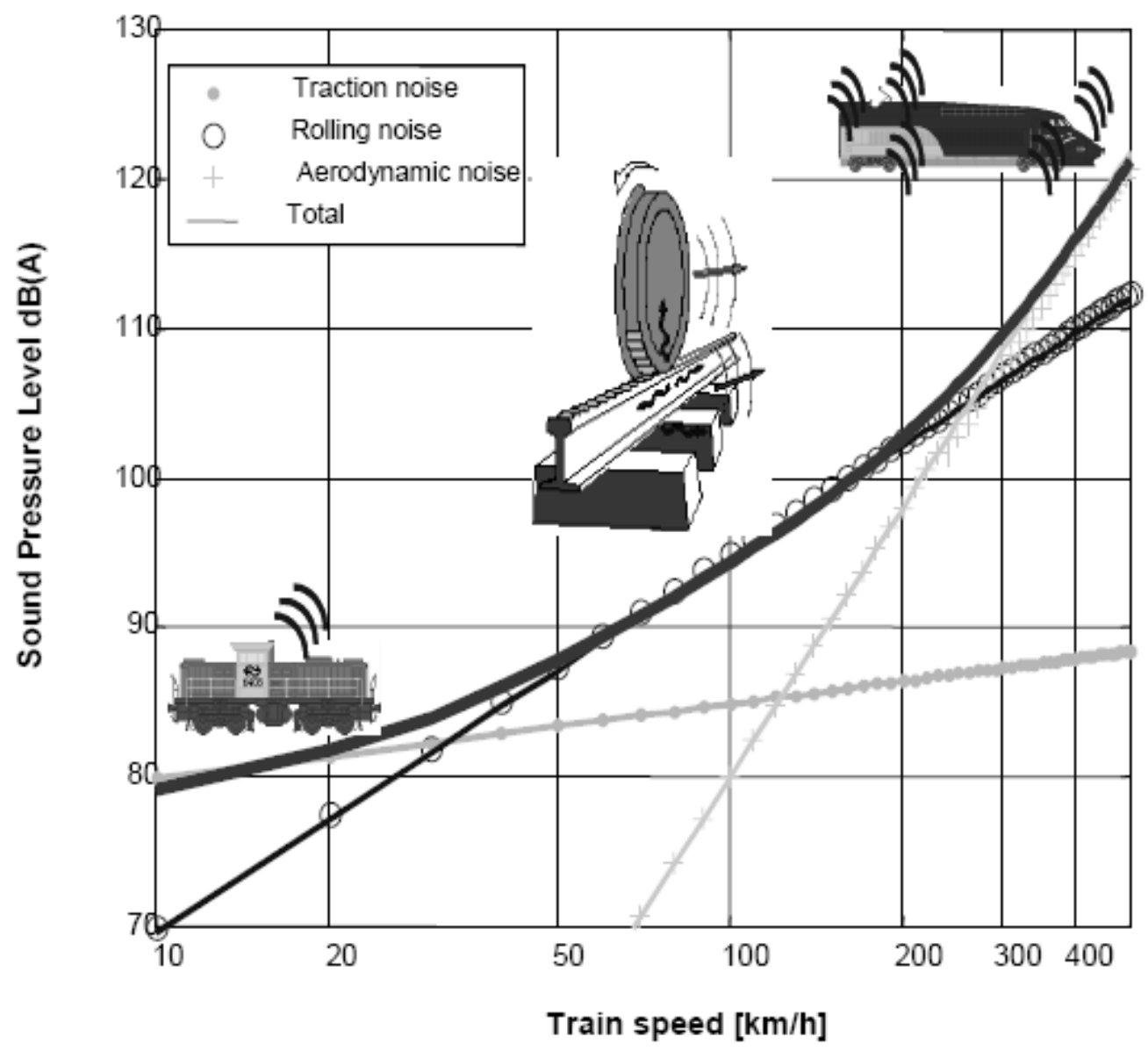

Figure 2: Rail exterior sound sources and their typical dependence on train speed.

(Hemsworth, 2008) 
People living near transport infrastructure are irritated by noise. The number of European citizens disturbed by traffic noise is increasing due to the growing demand for transport. The European Commission has implemented the Directive on Environmental Noise No. 2002/49/EC. In this Directive a noise indicator LDEN was defined for monitoring noise levels during the day, evening, and night. Based on this Directive the noise mapping of major roads, railways and airports was carried out in each Member State.

The graph in the Figure 3 (Rail transport and environment, 2008) shows the percentages of citizens disturbed by air, road, and rail traffic noise during the night.

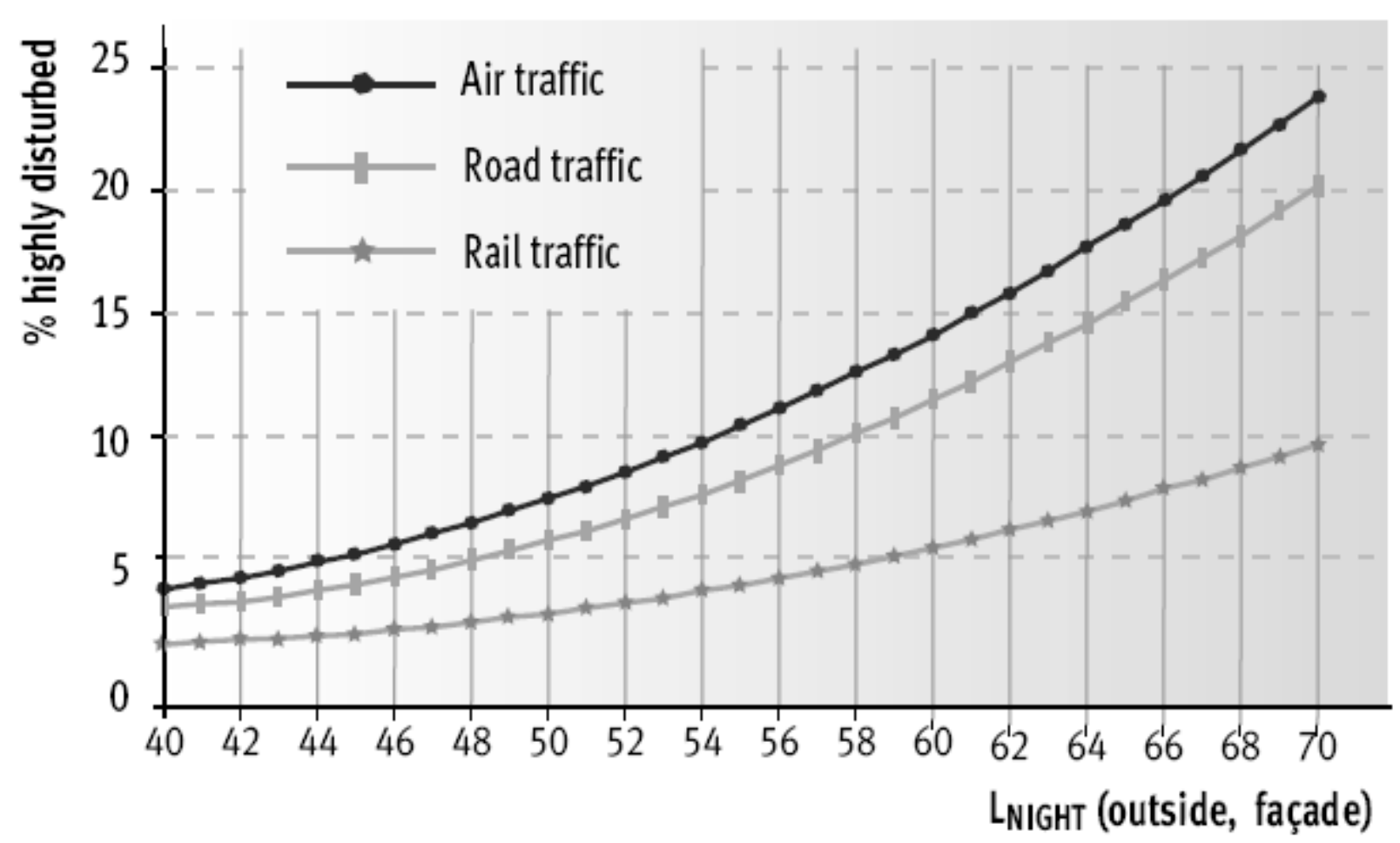

Figure 3: Percentages of citizens disturbed by traffic noise.

(Rail transport and environment, 2008)

\section{DIRECTIVES ON INTEROPERABILITY}

The term interoperability is defined as the ability of the rail system to allow the safe and uninterrupted movement of trains, which clearly implies the integration of the railway system. The following text shows that first high speed railways were dealt with. The reason for this is that high speed lines are relatively new and still evolving.

The Directive on the interoperability of conventional routes, which faces many problems, the majority of which stem from the standpoint of their historical development, came later. Infrastructure, as well as rolling stock, was designed according to national specifications and there is a large difference between countries that virtually prevents any merger.

The Trans-European railway network can consist only of tracks in which the compatibility between the characteristics of rolling stock, including the boarding systems and the characteristics of railway transport routes, can be guaranteed.

Individual subsystems are related to interoperability, and can be divided into either structural or operating. The structural subsystem mainly includes the infrastructure and vehicles, as well 
as traffic management, control, and the arrangement of the energy. The operating subsystem consists of maintenance and telematics applications.

Interoperability is the ability of diverse systems to work together. In the rail sector interoperability is a European Commission initiative to promote a single market. There have been several directives adopted by the European Council since 1996 (see the graph in Fig. 4).

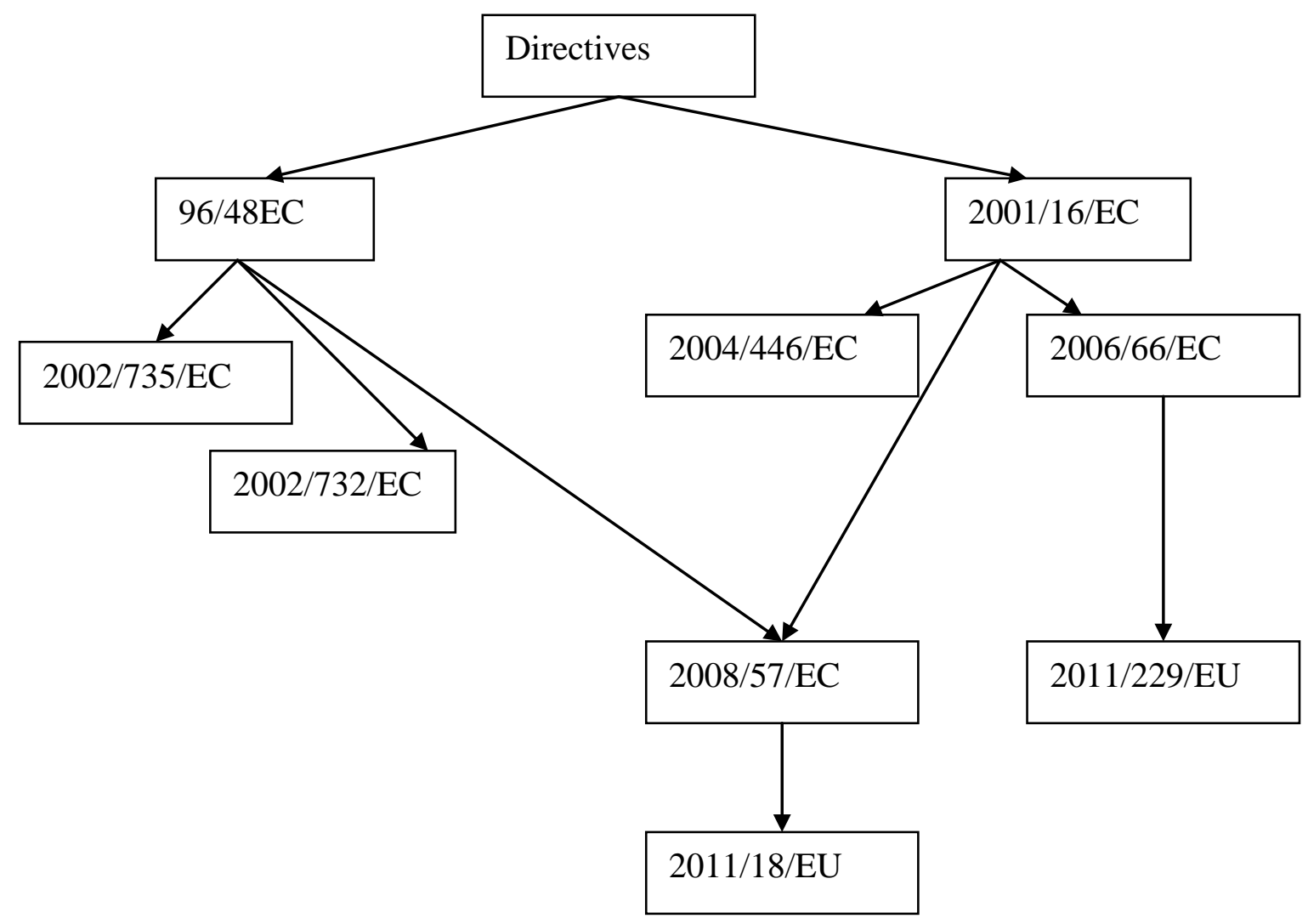

Figure 4: Directives on interoperability according to rolling stock.

The first was the Council Directive on the Interoperability of the Trans-European high-speed rail system - Directive 96/48/EC. This Directive was followed by two Technical Specifications for Interoperability (TSI); Technical Specification for Interoperability, relating to high-speed rolling stock - Commission Decision 2002/735/EC, and Technical Specification for Interoperability, relating to high-speed railway infrastructures - Commission Decision 2002/732/EC.

The second was the Council Directive on the Interoperability of the conventional TransEuropean rail system - Directive 2001/16/EC. This Directive came later, due to the diversity of the conventional rail system. There were two Commission Decisions relating to this Directive 2001/16/EC with the Technical Specifications for Interoperability of the conventional Trans-European rail system - Commission Decision 2004/446/EC, specifying the basic parameters of the 'Noise', 'Freight Wagons' and 'Telematic applications for freight', and Commission Decision 2006/66/EC, concerning the technical specification for interoperability relating to the subsystem "rolling stock - noise“. 
The TSI document states that the Commission will consider options for the retrofitting of freight wagons for noise reduction with stakeholders and the rail industry. TSIs include noise limits for starting noise, constant speed and stationary vehicles, as well as a track specification.

Both basic Directives on Interoperability (96/48/EC and 2001/16/EC) have evolved over the years and were replaced with a new directive. In July 2008 the European Parliament and Council Directive 2008/57/EC on the interoperability of the rail system came into force, which superseded both of the above Directives.

This directive installs the conditions to be fulfilled to achieve interoperability within the EU rail system at the construction, design, placing into service, upgrading, renewal, operation, and maintenance stages.

The gradual implementation of the interoperability of the rail system is being realized through the harmonisation of technical standards. Therefore this directive covers three main sections. The first covers the essential requirements with regard to safety, human health, environmental protection, reliability, technical compatibility, and operation of the system. The second comprises the technical specification for the interoperability adopted for each subsystem pursuant to this directive. The last part contains the corresponding European specification.

In March 2011, Commission Directive No 2011/18/EU was adopted. This Directive amends Annexes II, V and VI of the European Parliament and Council Directive 2008/57/EC on the interoperability of the rail system within the European Community.

In terms of the rail noise issue 2011/229/EU Commission Decision of 4 April 2011 is important, which concerns the technical specifications for interoperability relating to the "rolling stock - noise" of the trans-European conventional rail system, which voided and replaced the Commission Decision 2006/66/EC.

\section{NOISE FROM RAIL TRANSPORT WITHIN DIRECTIVES ON INTEROPERABILITY}

Noise of rail transport, particularly freight transport, significantly affects the lives of people around the transport infrastructure and it is therefore necessary to implement measures for its reduction. Measures to reduce noise from railway transport can either be of a technical or legislative basis.

The first group of measures related to railway noise management involved (Transport and Environment, 2011):

- Track type and quality - including wheel-rail rolling contact

- Quieter rolling stock and operation

- Railway structures and noise barriers

- Spatial planning and urban design

- Building insulation

The second group of measures is characterized by the leading role of the European Union. One of the many activities designed to reduce noise levels in the population is to define its limits. The European Union can play a major role in reducing noise through legislation via interoperability directives and also via the creation of technical standards for interoperability (TSI), which include noise standards for equipment and railway infrastructures.

When operating the trans-European conventional rail system must respect existing regulations on noise in accordance with Annex III to Directive 2008/57/EC. For the subsystem rolling stock four chapters in Decision No 2011/229/EU are specified - stationary noise, starting 
noise, pass-by noise, and driver's cab interior noise. The following Table 1 shows the limit values for the pass-by noise of freight wagons. This table was chosen from Decision No 2011/229/EU, due to freight transport being a significant producer of rail traffic noise.

Table 1: Limiting values $L_{\text {pAeq,Tp }}$ for the pass-by noise of freight wagons (2011/229/EU).

\begin{tabular}{|l|c|}
\hline Wagons & LpAeq,Tp in dB \\
\hline $\begin{array}{l}\text { New wagons with an average number of axles per unit length } \\
\text { (apl) up to } 0.15 \mathrm{~m}-1 \text { at } 80 \mathrm{~km} / \mathrm{h}\end{array}$ & 82 \\
\hline $\begin{array}{l}\text { Renewed or upgraded wagons according Article } 20 \text { of } \\
\text { Directive 2008/57/EC with an average number of axles per } \\
\text { unit length (apl) up to } 0.15 \mathrm{~m}-1 \text { at } 80 \mathrm{~km} / \mathrm{h}\end{array}$ & 83 \\
\hline $\begin{array}{l}\text { New wagons with an average number of axles per unit length } \\
\text { (apl) higher than } 0.15 \mathrm{~m}-1 \text { up to } 0.275 \mathrm{~m}-1 \text { at } 80 \mathrm{~km} / \mathrm{h}\end{array}$ & 85 \\
\hline $\begin{array}{l}\text { Renewed or upgraded wagons according Article } 20 \text { of } \\
\text { Directive 2008/57/EC with an average number of axles per } \\
\text { unit length (apl) higher than } 0.15 \mathrm{~m}-1 \text { up to } 0.275 \mathrm{~m}-1 \text { at } 80 \\
\text { km/h }\end{array}$ & 85 \\
\hline $\begin{array}{l}\text { New wagons with an average number of axles per unit length } \\
\text { (apl) higher than } 0.275 \mathrm{~m}-1 \text { at } 80 \mathrm{~km} / \mathrm{h}\end{array}$ & 87 \\
\hline $\begin{array}{l}\text { Renewed or upgraded wagons according Article } 20 \text { of } \\
\text { Directive 2008/57/EC with an average number of axles per } \\
\text { unit length (apl) higher than } 0.275 \mathrm{~m}-1 \text { at } 80 \mathrm{~km} / \mathrm{h}\end{array}$ & \\
\hline
\end{tabular}

\section{CONCLUSION}

This article summarizes the development of European Directives on the Interoperability of the Trans-European high-speed rail system and the Interoperability of the conventional Trans-European rail system from 1996 until 2011. The text makes it clear that noise is considered one of the key side effects of transport. The graph in figure 3 shows the time development of Interoperability Directives.

Very important documents in the fight against noise are EU Directive 2000/14/EC relating to the Harmonized noise emission of machines, products and equipment, and Directive 2002/49/EC on the assessment and management of environmental noise, known by the abbreviation END (Environmental Noise Directive). The aim of this Directive, which the EU Member States adopted as a solution to the acoustic conditions from a long-term 
strategic perspective, is to provide a uniform procedure for the long-term reduction of noise in the environment.

Other EU documents that are directly related to noise from rail transport were two key Directives - Directive 96/48/EC on the interoperability of the trans-European high-speed railways, and Directive 2001/16/EC on the interoperability of the trans-European conventional rail tracks. These Directives were replaced by the Council Directive 2008/57/EC on the interoperability of the rail system, and in 2011 were amended through Commission Directive 2011/18/EU.

\section{ACKNOWLEDGEMENT}

This research has been supported by TA01030087 "Influence Measures on Railway Infrastructure to Reduce Emergence and Spread of Noise from Moving Trains” and MSM 6840770043 "Development of methods of design and operation of transport networks from the point of view of their optimization“.

\section{REFERENCES}

European Union. Directive 96/48/EC on the interoperability of the trans-European high-speed rail system, 1996. In Official Journal of the European Union [online]. L235, pp. 6-24 [cit. 2012-12-02]. Retrieved from: http://eurlex.europa.eu/LexUriServ/LexUriServ.do?uri= CELEX:31996L0048:en:HTML

European Union. Directive 2001/16/EC on the Interoperability of the conventional TransEuropean rail system, 2001. In Official Journal of the European Union [online]. L0016, pp. 1-33 [cit. 2012-12-02]. Retrieved from: http://eurlex.europa.eu/LexUriServ/site/en/consleg/ 2001/L/02001L0016-20040430-en.pdf

European Union. Directive 2008/57/EC on the interoperability of the rail system, 2008. In Official Journal of the European Union [online]. L191, pp. 1-45 [cit. 2012-11-24]. Retrieved from: http://eurlex.europa.eu/LexUriServ/LexUriServ.do?uri=OJ:L:2008:191: 0001:0045:EN:PDF

European Union. Directive 2011/18/EU amending Annexes II, V and VI to Directive 2008/57/EC, 2011. In Official Journal of the European Union [online]. L57, pp. 21-28 [cit. 2012-11-24]. Retrieved from: http://eurlex.europa.eu/LexUriServ/LexUriServ.do?uri=OJ:L:2011:057: 0021:0028:EN:PDF

European Union. Commission decision 2011/229EU concerning the technical specifications of interoperability relating to the subsystem 'rolling stock - noise' of the trans-European conventional rail system, 2011. In Official Journal of the European Union [online]. L 99, pp. 1-39 [cit. 2012-11-24]. Retrieved from: http://eurlex.europa.eu/LexUriServ/LexUriServ. do?uri=OJ:L:2011:099:0001:0039:EN:PDF

Hemsworth, B., 2008. Environmental Noise Directive Development of Action Plans for Railways [online]. Paris: UIC [cit. 2011-08-18]. Retrieved from: http://www.uic.org/ IMG/pdf/Action_Planning_Paper_Final-2.pdf 
Rail transport and environment: Facts and figures [online], 2008. Paris: UIC, CER [cit. 2011-08-18]. Retrieved from:http://www.uic.org/IMG/pdf/railways_environment_facts_ figures_nov2009.pdf

Transport and Environment [online], 2011. Railway noise [cit. 2011-08-19]. Retrieved from: http://www.transportenvironment.org/module-htmlpages-display-pid-22.html\#2 